http://dx.doi.org/10.11646/zootaxa.3869.4.5

http://zoobank.org/urn:lsid:zoobank.org:pub:CB38DF91-EC70-4B17-9B9A-18C949431C1D

\title{
Apistogramma ortegai (Teleostei: Cichlidae), a new species of cichlid fish from the Ampyiacu River in the Peruvian Amazon basin
}

\author{
RICARDO BRITZKE ${ }^{1}$, CLAUDIO OLIVEIRA ${ }^{1} \&$ SVEN O. KULLANDER ${ }^{2}$ \\ ${ }^{1}$ Universidade Estadual Paulista, Instituto de Biociências, Departamento de Morfologia, Rubião Jr. s/n. CEP 18618-970. Botucatu, \\ SP,Brazil.E-mail:britzker@gmail.com \\ ${ }^{2}$ Department of Zoology, Swedish Museum of Natural History, PO Box 50007, SE-104 05 Stockholm, Sweden
}

\begin{abstract}
Apistogramma ortegai, new species, is described from small streams tributaries of the Ampiyacu River near Pebas, in eastern Peru. It belongs to the Apistogramma regani species group and is distinguished from all other species of Apistogramma by the combination of contiguous caudal spot to bar 7, presence of abdominal stripes, short dorsal-fin lappets in both sexes, absence of vertical stripes on the caudal fin, and reduced number of predorsal and prepelvic scales.
\end{abstract}

Key words: Geophaginae, Geophagini, Amazonia, Freshwater, Morphology, Taxonomy

\section{Resumen}

Apistogramma ortegai, nueva especie, es descrita desde pequeños tributario del rio Ampiyacu cerca de Pebas, en el este del Perú. Pertenece al grupo de especies de A. regani y es distinguido de todas las otras especies de Apistograma por la combinación de la barra 7 conectada con una mancha en la aleta caudal, presencia de líneas abdominales, membranas de la aleta dorsal cortas en ambos sexos, ausencia de líneas verticales en la aleta caudal, y reducido número de escamas predorsales y prepélvicas.

\section{Introduction}

The South American cichlid genus Apistogramma Regan (1913) comprises 84 valid species (Schindler \& Staeck, 2013) distributed in the basins of the Amazon, Orinoco, Paraguay, lower Paraná and Uruguay, and coastal rivers of the Guianas (Kullander, 2003). Kullander (1980) characterized the genus based on the combination of gill-rakers on the sides of the lower pharyngeal tooth-plate; a compressed lobe on the first epibranchial bone bearing gillrakers on the margin; three, rarely four anal-fin spines and 14-18 dorsal-fin spines. All species are of small size, the largest species not exceeding $60 \mathrm{~mm}$ in body length. They are sex dimorphic. Males grow larger than females and often have relatively larger fins, prolonged rays in the dorsal and caudal fins, and a filamentous extension of the first pelvic-fin ray, while sexually active females have species specific patterns consisting of black blotches and stripes against intense yellow background.

Eighteen valid species of Apistogramma have been described on the basis of material from the Peruvian Amazon basin, viz., A. allpahuayo Römer, Beninde, Duponchelle, Díaz, Ortega, Hahn, Soares, Cachay, Dávila, Cornejo \& Renno, 2012 (Nanay River); A. atahualpa Römer, 1997 (Nanay River); A. baenschi Römer, Hahn, Römer, Soares \& Wöhler, 2004 (Huallaga basin); A. barlowi Römer \& Hahn, 2008 (Ampiyacu River); A. cinilabra Römer, Duponchelle, Römer, Duponchelle, Diaz, Davilla, Sirvas, Catchay \& Renno, 2011 (Itaya River); $A$. cruzi Kullander, 1986 (Mazán River); A. eremnopyge Ready \& Kullander, 2004 (Pintuyacu River, Itaya River drainage); A. eunotus Kullander, 1981 (Ucayali River); A. huascar Römer, Pretor \& Hahn, 2006 (Nanay River); A. luelingi Kullander, 1976 (Madre de Dios and Mamoré River basins); A. martini Römer, Hahn, Römer, Soares \& Wöhler, 
2003 (Nanay River); A. nijsseni Kullander, 1979 (Copal River, Ucayali River drainage); A. norberti Staeck, 1991 (Tahuayo and Tamshiyacu Rivers); A. panduro Römer, 1997 (Ucayali River); A. pantalone Römer, Römer, Soares \& Hahn, 2006 (Nanay River); A. paulmuelleri Römer, Beninde, Duponchelle, Garcia Dávila, Vela Díaz \& Renno, 2013 (Amazon River); A. rositae Römer, Römer \& Hahn, 2006 (Marañón River) and A. urteagai Kullander, 1986 (Madre de Dios River). The first species referred to Apistogramma from Peru was described by Cope (1872) as Geophagus amoenus from the Ampiyacu River in Peru. Unfortunately, the type material is lost (Kullander, 1986) and the description is not detailed enough to identify the species (Kullander, 1980; 1981; 1986). In an effort to resolve the problem of the identity of Geophagus amoenus, the senior author surveyed the Pebas area at the mouth of the Ampiyacu River. Numerous specimens of Apistogramma were obtained, among them representatives of a new species. This paper is dedicated to the description of the new species.

\section{Material and methods}

Measurements and counts were taken as described by Kullander $(1980,1986)$. Values in the parentheses indicate the number of specimens with a particular count and an asterisk indicates values of the holotype. Specimen lengths are given as standard length (SL). Scale rows are numbered as described by Kullander (1990). Counts of external openings of the infraorbital lateralis canal refer to the postlachrymal number, i.e., excluding the opening shared by the posterior lachrymal lateralis foramen and the anterior foramen of the first infraorbital bone. Color marking terminology follows Kullander (1980, 1986). For osteological observations, cleared and stained (c\&s) specimens were prepared according to Taylor \& Van Dyke (1985).

Institutional abbreviations: MUSM, Museo de Historia Natural, Universidad Nacional Mayor de San Marcos, Lima, Peru; NRM, Swedish Museum of Natural History, Stockholm, Sweden; LBP, Laboratório de Biologia e Genética de Peixes, Universidade Estadual Paulista "Júlio de Mesquita Filho", Campus de Botucatu, São Paulo, Brazil.

\section{Apistogramma ortegai, new species}

(Figs. 1-8)

Apistogramma sp. "Pebas" Koslowski, 2002: 90-91, fig.

Apistogramma sp. "Papagei" Koslowski, 2002: 90-91, fig.

Holotype. MUSM 48898, $38.4 \mathrm{~mm}$ SL; Peru, Departamento Loreto, Distrito Pebas: small stream tributary of Ampiyacu River, $03^{\circ} 18^{\prime} 46.1^{\prime \prime S}, 71^{\circ} 50^{\prime} 58.4^{\prime \prime W}, 13$ August 2011. C. Oliveira, M. Taylor, R. Britzke and J. Mori.

Paratypes. All from Peru, Departamento Loreto, vicinity of Pebas. Same date and collectors as holotype. LBP 12461, 14 (1 c\&s), 18.3-44.1 mm SL. LBP 12444, 9, 19.4-50.5 mm SL. NRM 66403, 10, 19.0-42.0 mm SL. MUSM 48899, 1, 32 mm SL. LBP 12463, 8, 22.8-45.2 mm SL. LBP 12455, 11 (5 c\&s), 24.5-37.0 mm SL.

Diagnosis. A species of the Apistogramma regani species group, sharing exclusively with A. commbrae (Regan, 1906); A. inconspicua Kullander, 1983; and A. linkei Koslowski, 1985 a tail spot (contiguous caudal spot to bar 7). Apistogramma ortegai differs from A. commbrae by absence of vertical stripes on caudal fin (vs. presence); from $A$. inconspicua by absence of vertical stripes on caudal fin (vs. presence) and by lateral band running into tail spot (vs. lateral band ending in bar 6); from A. linkei by absence of vertical stripes on caudal fin (vs. presence of two vertical stripes posteriorly) and by horizontal abdominal stripes (vs. vertical abdominal stripes). Distinguished from other species with similar general counts, body shape and similar basic melanic color pattern, with exception of the contiguous caudal spot to bar 7: from A. eunotus by predorsal scales 7-8 (vs. 9-12), prepelvic scales 6-8 (vs. 9-13) and presence of abdominal stripes (vs. absence); from A. cruzi by prepelvic scales 6-8 (vs. 9-13); from A. aguarico by dorsal-fin lappets short (vs. five first dorsal-fin lappets elongated).

Description. Morphometric and meristic data are presented in Table 1. Body moderately deep, laterally compressed. Snout triangular in lateral view. Predorsal outline straight, in some adult males slightly elevated. Dorsal-fin base and prepelvic outline straight and gently curved. Dentary lateral line canal with 5 pores; anguloarticular canal with 2 pores; infraorbital canal with 4 pores (Fig. 4). E1 row scales 21 (3), 22 (6), 23 (26). Tube-bearing scales in upper lateral line 7 (2), 8 (3), 10 (3), 11 (5), 12 (10), 13 (8), 14 (4). Pore-bearing scales in 
upper lateral line 1 (1), 2 (19), 3 (13), 4 (1). H1 row scales 6 (2), 7 (14), 8 (14), 9 (5). Tube-bearing scales in lower lateral line 3 (3), 4 (4), 5 (16), 6 (7), 7 (4). Pore-bearing scales in lower lateral line 1 (18), 2 (14), 3 (3). Predorsal scales 7-8. Prepelvic scales 6-8. Circumpeduncular scale rows 16. Dorsal-fin rays XV.6 (6), XV.7 (10), XVI.6 (11), XVI.7 (9). Anal-fin rays III.6 (29), III.7 (6). Pectoral fin rounded, pectoral-fin rays 12 (35). Pelvic fins with slightly extended tip extending beyond anal-fin origin. Dorsal fin relatively low, first spine half length of last spine, relative spine length increasing from first to third, lappets of first, second and third spines less than half length of respective spine, straight and gently curved. Dorsal spines sub-equal in length from the fourth to sixth or slowly increasing in length to last. In adult male much produced third to sixth lappets. Soft dorsal fin with bifurcate rays, posterior branch of second and anterior branch of third ray forming long filamentous tip reaching slightly beyond posterior margin of caudal fin. Gill rakers externally on first gill arch, 5 on lobe, 1 in angle, and 2 (5) on ceratobranchial. Vertebrae $13+11=24(6)$.

TABLE 1. Morphometric data from holotype and paratypes of Apistogramma ortegai. Standard length (SL) is expressed in millimeters, all other measurements are expressed as percentage of SL.

\begin{tabular}{|c|c|c|c|c|c|c|}
\hline & Holotype & $\mathrm{N}$ & Paraty & & & \\
\hline & & & Mean & Min & Max & SD \\
\hline Standard length (mm) & 38.4 & 54 & 28.0 & 18.4 & 50.5 & 7.5 \\
\hline Head length & 34.9 & 35 & 35.2 & 31.5 & 39.7 & 1.7 \\
\hline Snout length & 11.7 & 35 & 9.3 & 7.4 & 11.8 & 1.0 \\
\hline Body depth & 33.2 & 35 & 33.7 & 31.1 & 36.5 & 1.5 \\
\hline Orbital diameter & 9.5 & 35 & 10.8 & 8.2 & 12.9 & 1.0 \\
\hline Head width & 17.3 & 35 & 17.7 & 15.4 & 20.4 & 1.0 \\
\hline Interorbital width & 11.3 & 35 & 11.7 & 10.0 & 13.4 & 0.9 \\
\hline Preorbital depth & 3.8 & 35 & 3.7 & 2.5 & 4.6 & 0.5 \\
\hline Caudal peduncle depth & 15.3 & 35 & 16.1 & 14.0 & 19.2 & 0.9 \\
\hline Caudal peduncle length & 9.4 & 35 & 98.0 & 5.9 & 12.3 & 1.7 \\
\hline Pectoral-fin length & 29.4 & 35 & 29.8 & 24.8 & 33.5 & 2.0 \\
\hline Pelvic-fin length & 37.1 & 35 & 33.0 & 27.2 & 41.4 & 3.5 \\
\hline Last dorsal-fin spine length & 15.2 & 35 & 15.3 & 11.4 & 19.8 & 2.3 \\
\hline Upper jaw length & 9.9 & 35 & 7.1 & 5.2 & 10.1 & 1.1 \\
\hline Lower jaw length & 10.8 & 35 & 10.3 & 8.6 & 12.6 & 0.9 \\
\hline
\end{tabular}

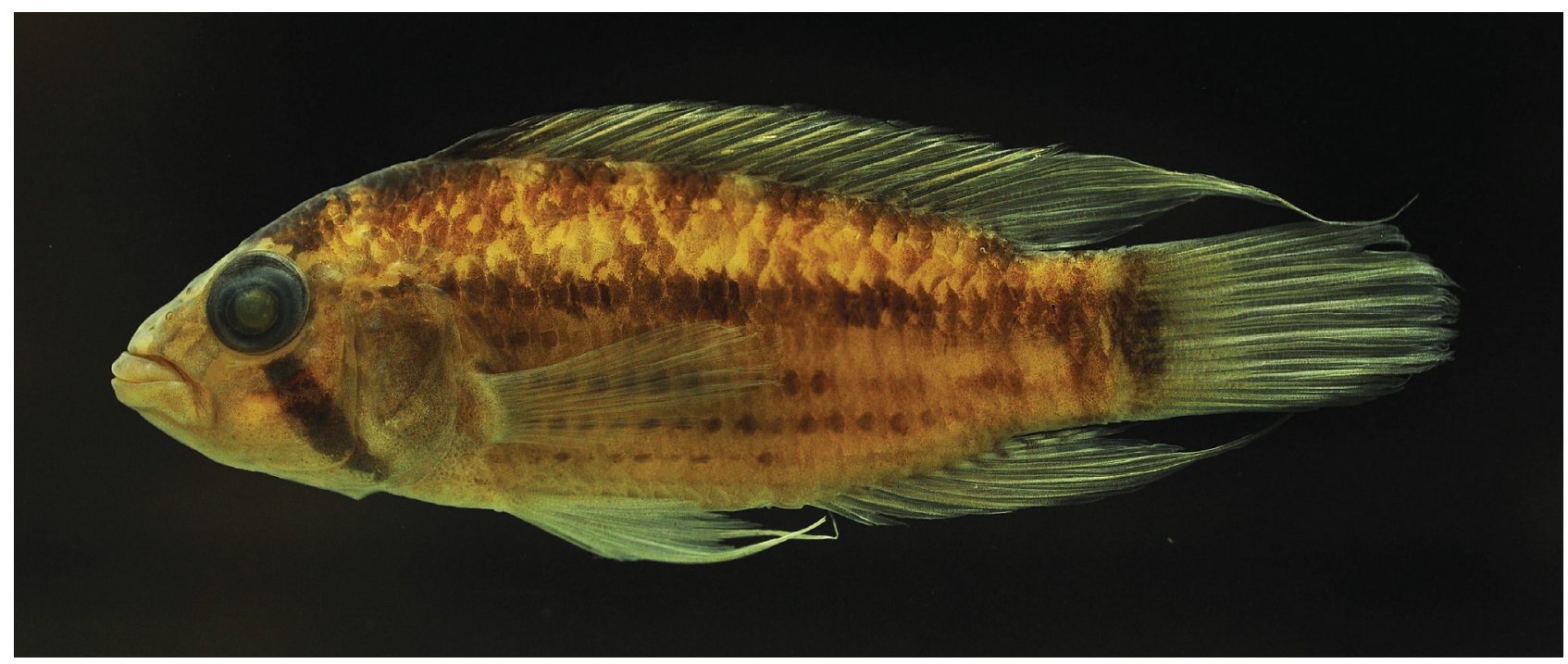

FIGURE 1. Apistogramma ortegai, holotype, male, MUSM 48898, 38.4 mm SL, Peru, Departamento Loreto, Distrito Pebas, small stream tributary of Ampiyacu River. 


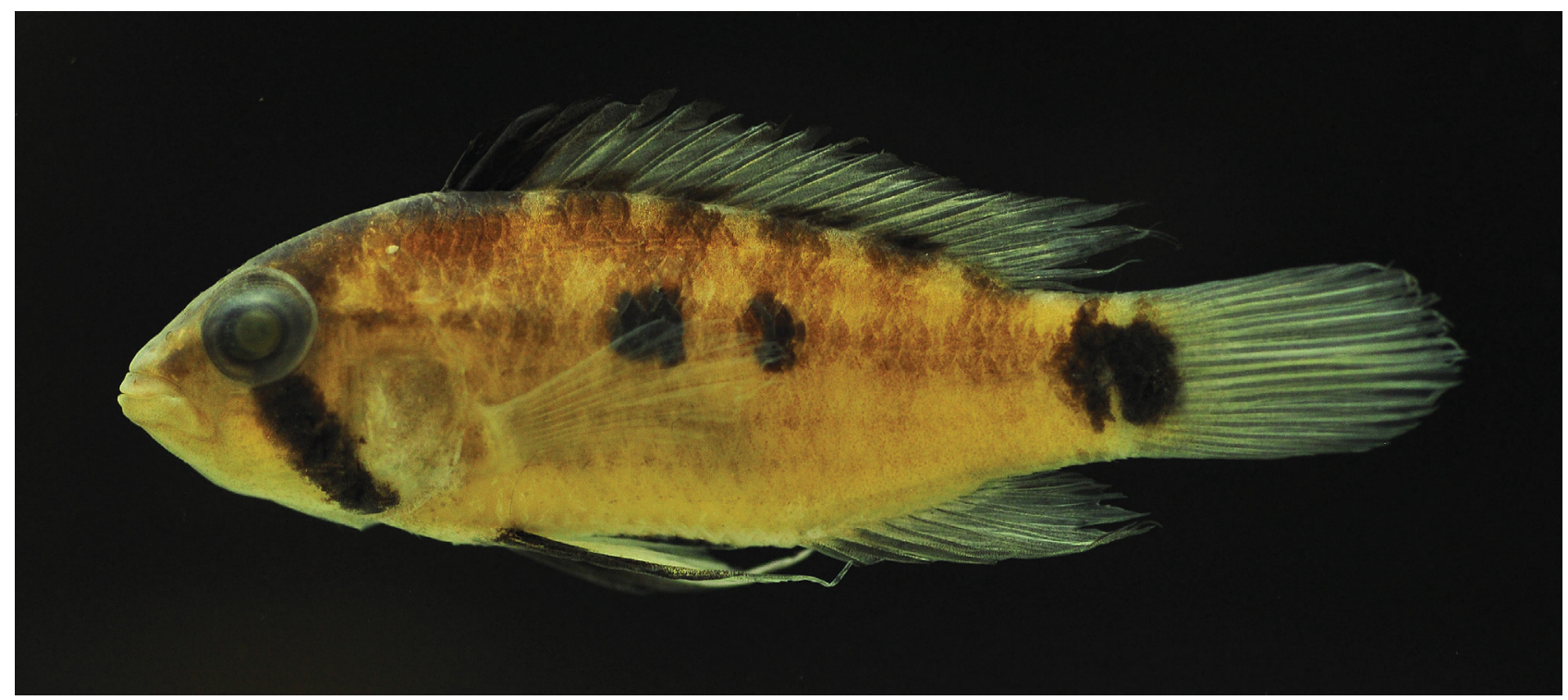

FIGURE 2. Apistogramma ortegai, paratype, female, MUSM 48899, 32 mm SL, Peru, Departamento Loreto, Distrito Pebas, small stream tributary of Ampiyacu River.

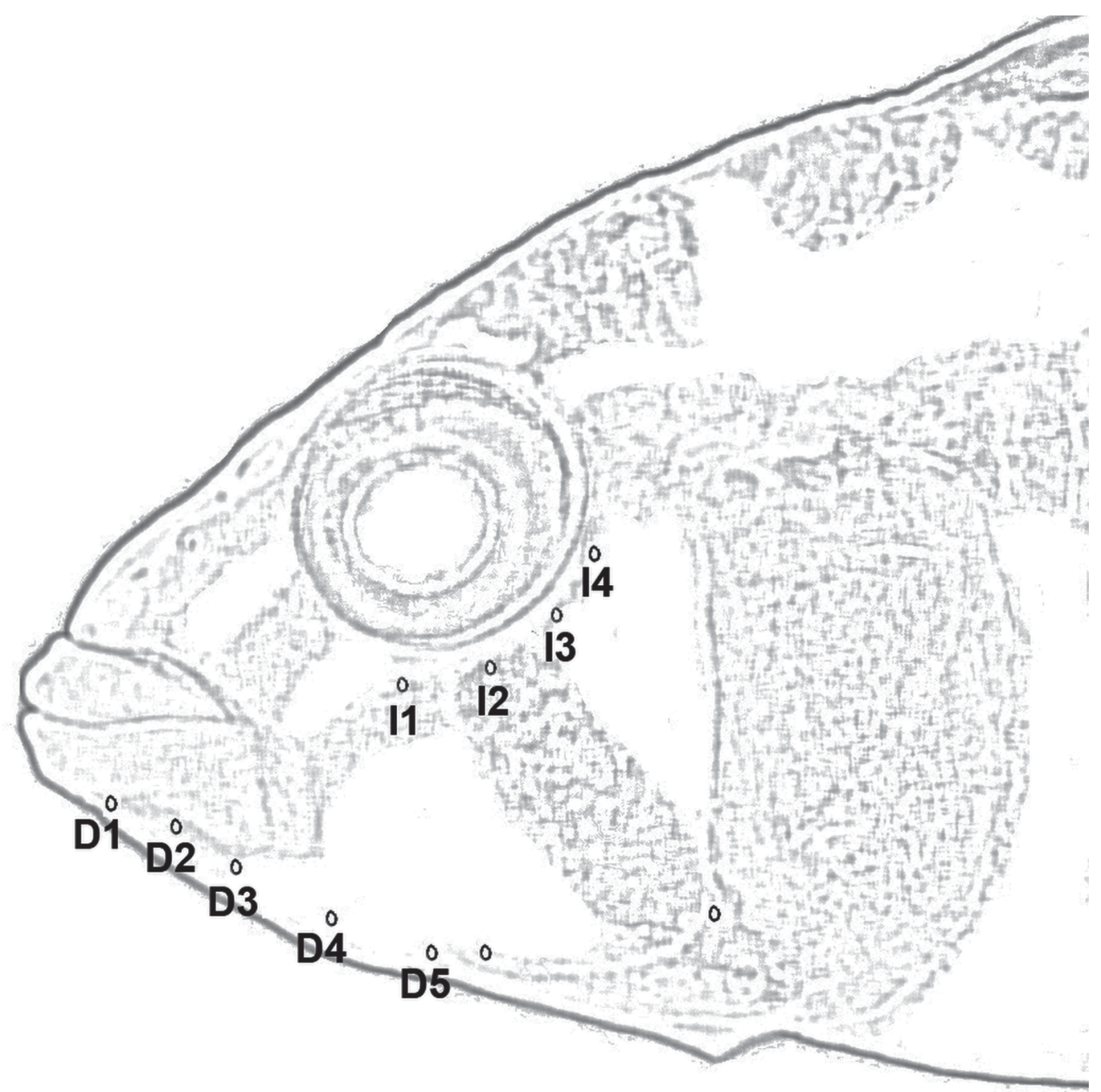

FIGURE 3. Distribution of cephalic lateralis pores in head of Apistogramma ortegai. 


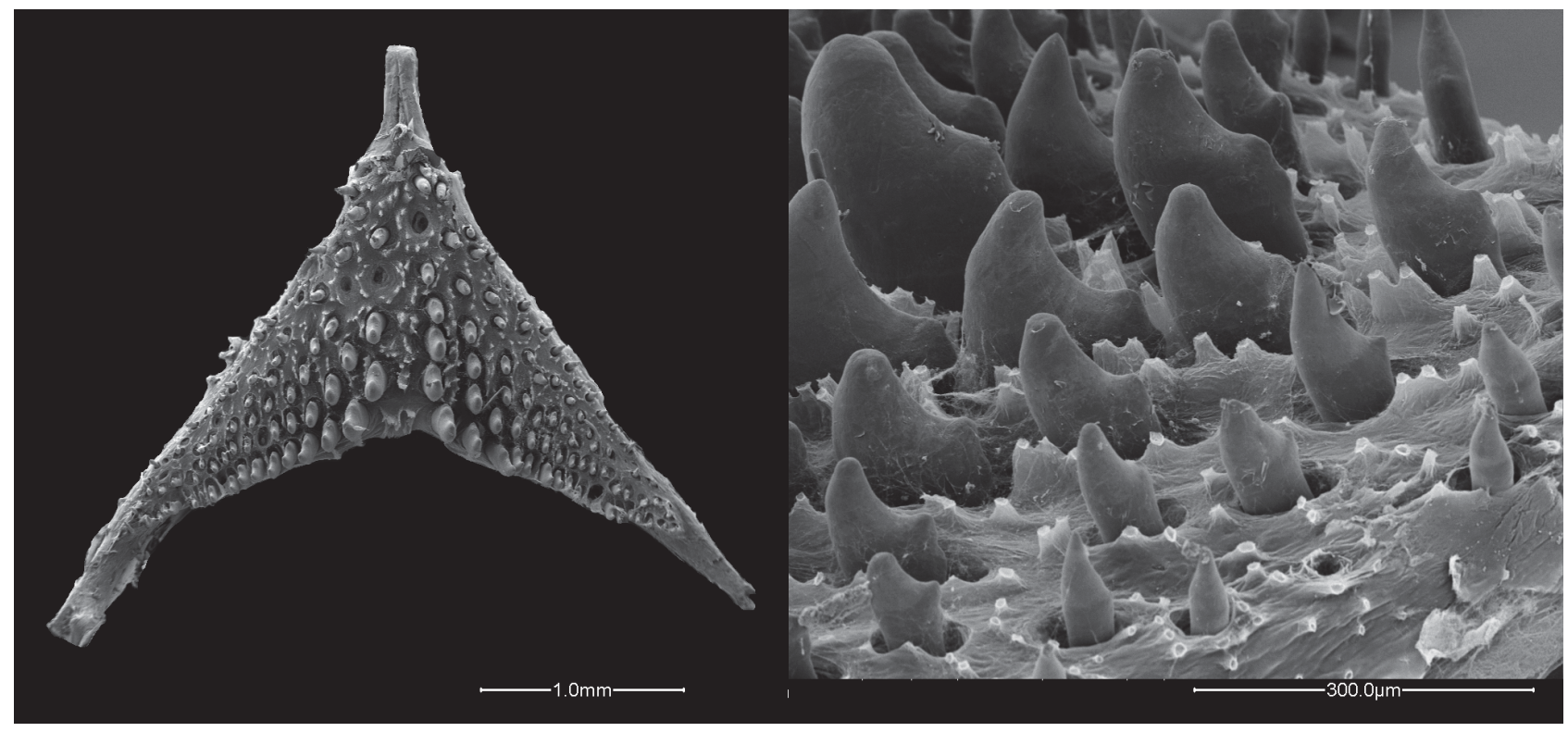

FIGURE 4. Apistogramma ortegai. Lower pharyngeal tooth-plate in occlusal view and detail of the teeth.

Color in preserved specimens. Basic color of body light beige in both sexes. Head usually slightly darker than body. Lips in both sexes grey, more intense in males. Brown markings and light grey lines on cheek present in males fixed in ethanol, absent in specimens fixed in formalin. Reticulated pattern on scales above lateral band. Dark vertical bars most distinct above lateral band. Caudal spot confluent with lateral band, usually indistinctly in males. Tail spot formed by dark spot at middle part of Bar 7 contiguous with dark spot at base of caudal fin and in some specimens drop-shaped (Fig. 6A, B), in others component spots forming a double-spot (Fig. 6C, D). Lateral band originating in narrow postorbital stripe, about one scale deep, running on E1scale series, extending posteriorly into tail spot. Suborbital stripe reaching ventrally to lower margin of preopercle. Preorbital between the anterior orbital rim and the upper lip. Preorbital stripe between anterior orbital rim and upper lip. Distinct, moderately wide supraorbital stripe from orbit dorsad. Dorsal fin dusky with some light spots posteriorly on soft-rayed portion, not forming conspicuous terminal spot stripes; anal fin similar. Lappets of dorsal fin white. Membranes of two anterior dorsal-fin spines black, darker areas at bar origins basally between spines. Caudal fin dusky, vertical stripes absent. Pectoral fin transparent. Pelvic fin mainly hyaline, spine and interradial membranes of anterior soft rays light grey. Abdominal markings consisting of horizontal stripes between every scale row, most distinct in first and second horizontal row below lateral band, from pectoral axilla to bar 4, less distinct posteriorly; and in third and fourth scale series below lateral band. In adult females usually 2-6 dark spots, each contained in a vertical bar, in middle region of body.

Color in life. Males (Fig. 5A): Basic color of body iridescent blue with red marks associated with scales dorsal to lateral band. Lips grey or light blue. Cheek sky blue with red markings. Anterior vertical bars indistinct; bars distinct in posterior part of side. Bar 7 connected to caudal spot, extending to root of caudal peduncle, usually not distinct in males. Dorsal fin distal margin dark gray; conspicuous red and sky blue vertical stripes increasing in intensity caudad. Lappets of dorsal fin red and sky blue. Anal fin yellow and light blue. The first spine and membrane of anal fin black. Caudal fin orangeish yellow. Pectoral fin transparent. Pelvic fins light yellow, spine and membranes of first rays light grey. No distinct lateral band. Abdominal markings consisting of three horizontal stripes as in preserved specimens; most distinct in first and second horizontal row below lateral band, from pectoral axilla to bar 4, less distinct posteriorly and in third and fourth scale series below lateral band.

Females (Fig. 5B): Basic color of body yellow, markings black. Dorsal fin yellow with dark distal margin. First and second spines and membranes of dorsal fin black. Base of dorsal with fin dark areas corresponding to vertical bars 3, 4, 5 and 6, distinct dorsally. Bars 3, 4 and 5 distinct below lateral band. First spine and membrane of pelvic fin black, remainder of fin yellow. Pelvic fin with black margin. Caudal fin yellow. Adult females generally with 2-6 spots contained within vertical bars. Caudal spot approximately square, confluent with bar 7. Abdominal markings consisting of three dark horizontal stripes as in preserved specimens; most distinct in first and second 
horizontal row below lateral band, from pectoral axilla to bar 4, less distinct more posteriorly and in third and fourth scale series below lateral band. Reproductive females show black midventral stripe, starting at end of pelvic fins, continued to anal opening.

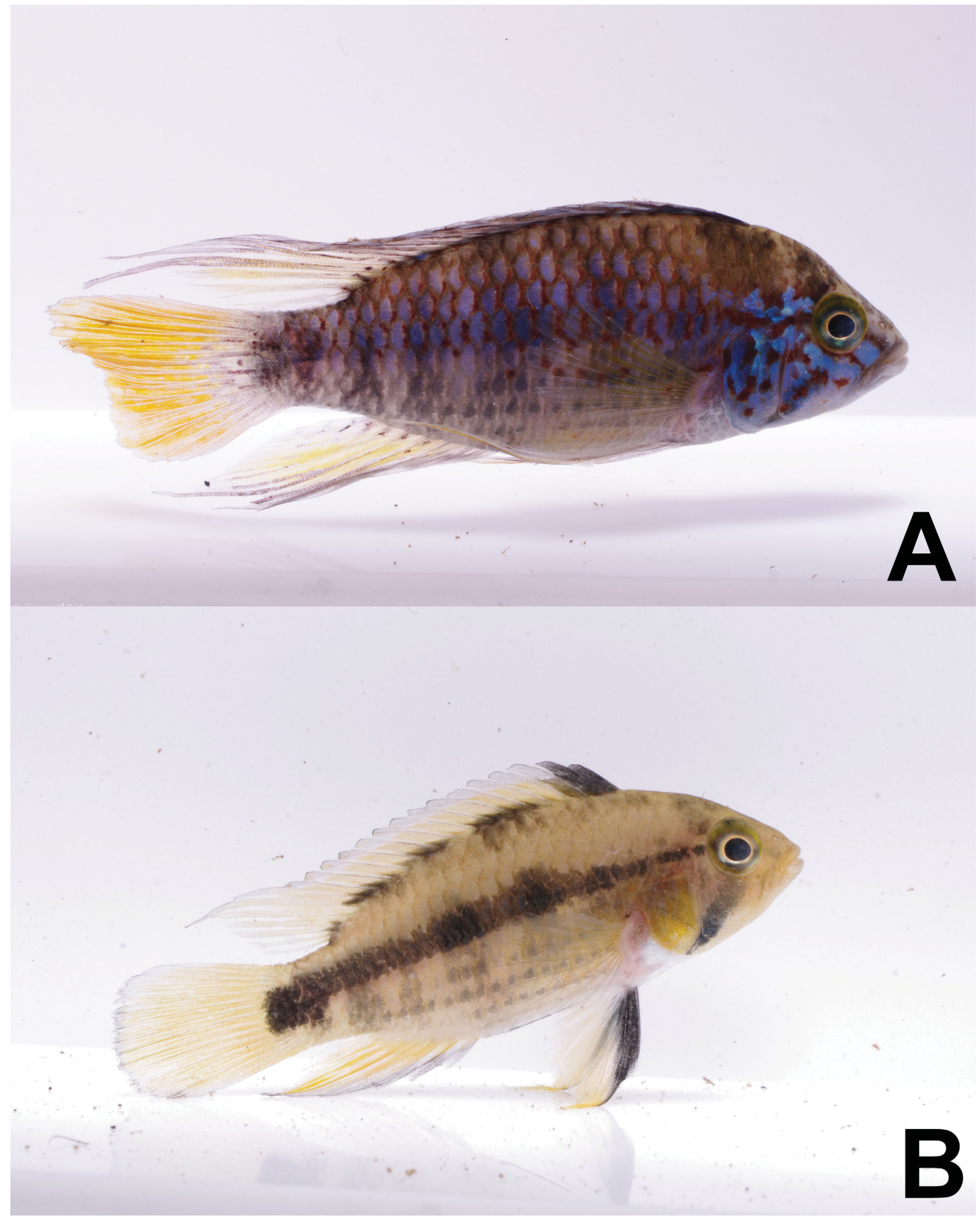

FIGURE 5. Apistogramma ortegai, live coloration in male (A) and female (B), collected with holotype. 


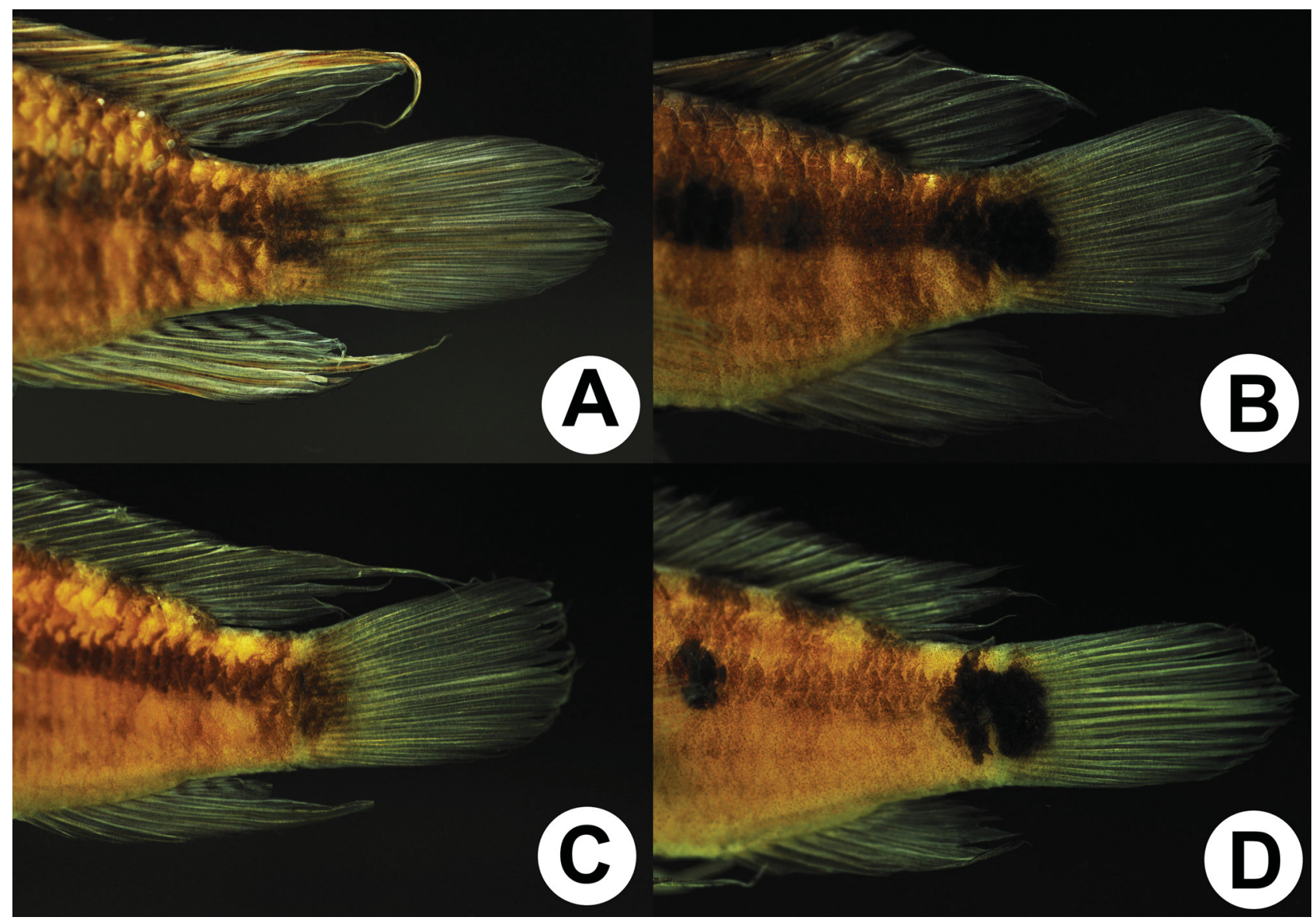

FIGURE 6. Variation in the shape of the caudal spot in Apistogramma ortegai. A. Male showing drop shape ("Pebas" form); B. Female showing drop shape ("Pebas" form); C. Male showing double-spot ("Papagey"; form) D. Female showing double-spot ( "Papagey" form).

Etymology. The specific name is given for Professor Hernán Ortega Torres, ichthyologist at the Museo de Historia Natural, Universidad Nacional Mayor de San Marcos, Lima, Peru, in recognition of his life-long dedication and contribution to the study of the fishes of Peru.

Distribution and habitat. Apistogramma ortegai is known only from a small stream (quebrada) tributary to the Ampyiacu River in the municipality of Pebas. All specimens were collected along the margin, with most of its area within a dense, difficult to access forest (Fig. 7). The stream had clear and acid water, pH 6.0, water temperature $26^{\circ} \mathrm{C}$, and a depth of at most $50 \mathrm{~cm}$. The bottom substrate was mainly comprised of sand and leaves, with some clay. Aquatic vegetation was not present. Species collected together with A. ortegai were $A$. bitaeniata, Bujurquina peregrinabunda, Crenicichla sp., Cichlasoma amazonarum, Acestrocephalus sp., Astyanax bimaculatus, Characidium sp., Knodus sp., Leporinus sp. aff. friderici, Moenkhausia margitae, Moenkhausia oligolepsis, Pyrrhulina semifasciata, Corydoras fowleri, Ituglanis sp., Rhamdia sp., Gymnotus sp., and Sternopygus macrurus.

\section{Discussion}

Cope (1872) described Geophagus amoenus from the Ampiyacu River and compared it with G. taeniatus (=Apistogramma taeniata), for which reason it has later been identified as a species of Apistogramma (e.g., Kullander, 1980, with a reconstruction based on Cope's description). Cope's description, based apparently on a single specimen, $63 \mathrm{~mm}$ long (probably total length), and subsequently lost (Kullander, 1980) is compatible with a species of Apistogramma, especially in the small size, the long dorsal and anal fins extending beyond the caudal fin, the pattern of blue spots and yellow lines on the side of the head a black spot at the base of the caudal fin, but 
differs in the possession of two spots associated with the caudal fin: "black spot at base, and one at the tip of the caudal fin". Steindachner (1875) synonymized G. amoenus with A. taeniata, based on specimens collected by the Thayer Expedition from Óbidos, Tefé, Tabatinga and the Tapajós River. Regan (1906) overlooked the species in his revision of Heterogramma (=Apistogramma), but later provided a description based on two specimens from the Ucayali River identified as A. amoena. Those specimens were included in the type series of $A$. eunotus by Kullander (1981). Kullander (1981) commented on A. amoena and concluded that Cope's description concerned a species with different fin shape, proportions and colour pattern from A. eunotus. None of the more than 80 species of Apistogramma so far described has a dark spot at the end of the caudal fin, and the possibility exists that the description of the spots on the caudal fin contains a lapsus calami. Apistogramma ortegai is similar to the description of $G$. amoenus (Cope, 1872) with reference to the lateral band extending from the orbit to the caudal-fin base (ending at the caudal spot) and counts of rays of the dorsal and anal fins. Compared with G. amoenus, A. ortegai does not have a black spot at the tip of the caudal fin, or an elongate body as estimated from the number of longitudinal scales cited by Cope (2-25-8 scales $=2$ above, 8 below lateral line, and 25 scales along the middle of the side), or the length of head less than the height of the body (see Kullander 1980, 1981).

Apistogramma ortegai conforms to the Apistogramma regani species group which is diagnosed by presence of vertical bars, lateral band, head stripes radiating from the orbit (suborbital, preorbital, postorbital, supraorbital); dark spot anteriorly in dorsal fin, 3-4 rows of jaw teeth, tubed scales in lower lateral line, relatively deep body, 1-4 ceratobranchial gill rakers, and absence of chest spot and lateral spot (Kullander 1980: 48).

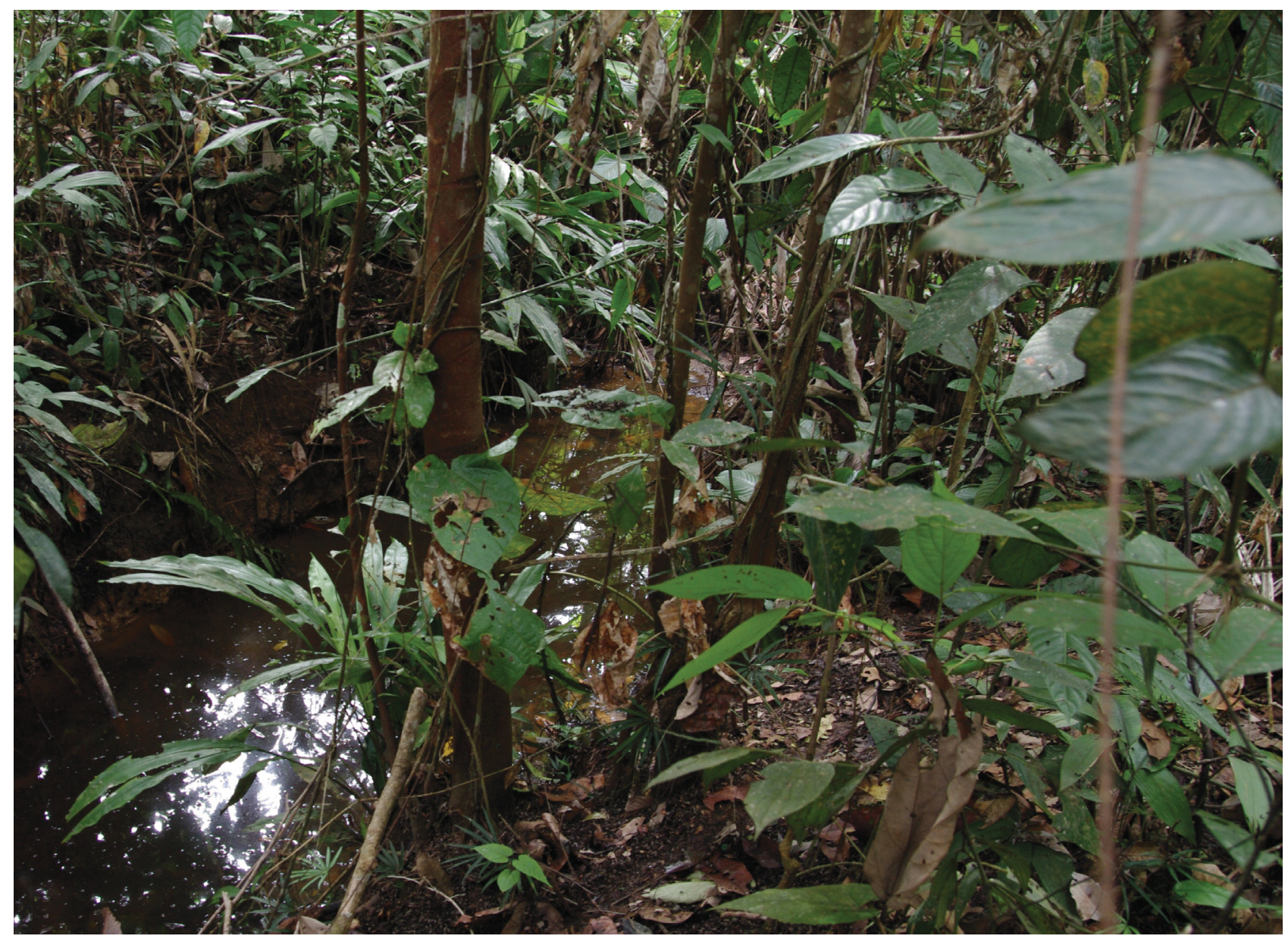

FIGURE 7. Type locality of Apistogramma ortegai. Peru, Departamento Loreto, Distrito Pebas, small stream tributary of Ampiyacu River.

Apistogramma ortegai differs from other species of Apistogramma mainly by the contiguous caudal spot and bar 7 forming a large spot across the posterior part of the caudal peduncle and the basal portion of the caudal fin. Within the A. regani species group this character is shared only with A. linkei (Bolivian Amazon), A. inconspicua (Bolivian Amazon and Paraguay River basin), and A. commbrae (Paraguay and lower Paraná basins), and is 
potentially a synapomorphy of these four species. An enlarged caudal spot covering the caudal peduncle and the caudal-fin base is also present in A. nijsseni and A. panduro. These two species exhibit a distinctive color pattern and have three infraorbital pores, and are consequently excluded from the $A$. regani group.

Koslowski (2002) distinguished two forms of Apistogramma from the Pebas area in which the caudal spot is confluent or contiguous with the lateral band, called "Pebas" (lateral band extending to bar 7 and connecting to caudal spot forming a drop-shaped spot) and "Papagei" (lateral band extending to bar 7 and connecting to caudal spot forming sort of double-spot), respectively. Both obviously agree in all regards with the material here referred to A. ortegai. Although he presented them as as undescribed species, Koslowski noted that the two forms possibly only represent intraspecific variation. Our morphological data from A. ortegai does not permit recognition of more than one species, and consequently "Papagei" and "Pebas" are both included in the concept of $A$. ortegai.

Variation in the melanic color pattern preserved in formalin-fixed specimens is a prominent source of species diagnostic character states among South American cichlids, including Apistogramma (e.g., Kullander, 1990, 1986). In some cases, however, colour pattern variation has been explained as intraspecific. Staeck \& Kullander (1988), describing A. paucisquamis from the Negro River (Santa Isabel do Rio Negro to Manaus, Amazon state, Brazil), reported that males of this species have three color forms. Römer (1994) describing A. mendezi from Barcelos (Amazonas state, Brazil), stated that the eastern population exhibits horizontal lines on the caudal fin, while the western population has vertical lines on the caudal fin. As treated by those authors there is intraspecific discrete minor variation in the color pattern of some species of the genus Apistogramma but separate species status is not supported by other morphological characters.

There is, however, at least one cryptic group of species with minimal color differences but diagnosable by molecular characters, described by Ready et al. (2006). They analyzed Apistogramma populations of eastern Amazon from four localities, and recognized genetically three species within what has been described as A. caetei. Morphologically, all three species possess the characteristics of A. caetei (see Kullander, 1980), and have no diagnostic characters for species delimitation other than details of coloration. Ready et al. (2006) suggest that these species probably are still going through a process of speciation, following a recent allopatric divergence. Ready et al. (2006) conclude that the species studied present genetic structuring, but little morphological variation.

The western Amazon is an important area of endemism for some lineages of cichlids (Kullander, 1986), as exemplified by the many species of Apistogramma described from the Peruvian and Ecuadorian Amazon basin.

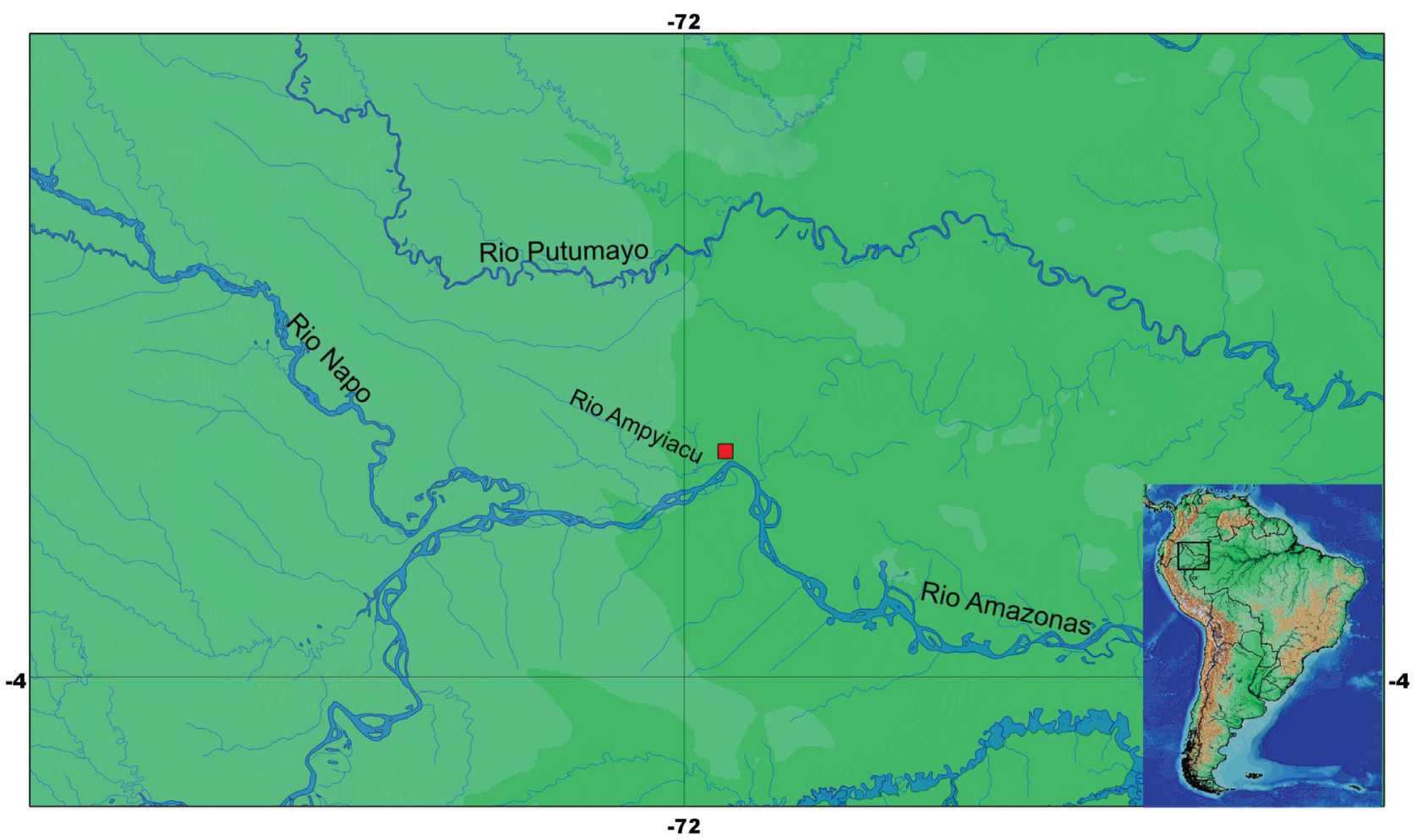

FIGURE 8. Map showing the type locality of Apistogramma ortegai. 


\section{Comparative material}

Apistogramma caetei: LBP 9437, 5, 28.7-38.7 mm SL, Brazil, Pará, Caeté River basin, Tracuateua, Igarape Cajueirinho, Tracuateua. Apistogramma cinilabra: LBP 12567, 2, 30.4-44.7 mm SL, Peru. Apistogramma cruzi: NRM 16664, holotype, $25.9 \mathrm{~mm}$ SL, Peru, tributary to the Mazán River. Apistogramma commbrae: LBP 11493, 1, $25.5 \mathrm{~mm}$ SL, Brazil, Mato Grosso, Poconé; LBP 5233, 5, 24.5-26 mm SL, Brazil, Paraná, Porto Rico. Apistogramma eunotus: LBP 17750, 1, $44.6 \mathrm{~mm}$ SL, Peru, Loreto, quebrada on the Carretera Campo Verde to Tournavista. Apistogramma inconspicua: MZUSP 38944 , 1, paratype, $23.5 \mathrm{~mm}$ SL, Bolivia, Santa Cruz, Candelaria River. Apistogramma linkei: MZUSP 28726, 8, paratypes, 17.7-25.7 mm SL, Bolivia, Beni, NW Santa Cruz. Apistogramma megaptera: IAvH 11714, 1, holotype, $38.1 \mathrm{~mm}$ SL, Colombia, Guainía, caño Matadero. Apistogramma personata: MZUSP 81489, 5, 38.1-51.7 mm SL, Brazil, Amazonas, Tiquié River basin, Igarapé Mipiriypotemakaya. Apistogramma regani: LBP 17856, 2, 18.9-25.2 mm SL, Brazil, Amazonas, Iranduba. Apistogramma resticulosa: LBP 11468, 5, 25.4-38.7 mm SL, Brazil, Amazonas, Humaitá. Apistogramma steindachneri: ROM 82022, 1, 37.5 mm SL, Guiana, Berbice River basin. Apistogramma taeniata: LBP 14255, 5, 13.1-25 mm SL, Brazil, Pará, Itaituba. Apistogramma urteagai: ROM 82818, 1, 24.5 mm SL, Peru, Madre de Dios, Tambopata Natural Reserve, Kati Cocha.

\section{Acknowledgements}

We thank Jonathan S. Ready (UFPA) for comments and suggestions on the manuscript, and anonymous reviewers provided constructive comments that significantly improved the original manuscript. Hernán López-Fernández, Don Stacey and Erling Holm (ROM), Osvaldo Oyakawa and Michel Gianeti (MZUSP) for the loan part of the material used in this study, Claudia Medina and Carlos Montaña (IAvH) for allowing access to the collection of the Instituto Humboldt, Martin Taylor (University of East Anglia) for pictures of live specimens, Jorge Mori and Martin Taylor for help in the field. RB is financially supported by FAPESP (Proc. 2011/00269-4).

\section{Literature cited}

Cope, E.D. (1872) On the fishes of the Ambyiacu River. Proceedings of the Academy of Natural Sciences of Philadelphia, 23, 250-294.

Koslowski, I. (1985) Descriptions of new species of Apistogramma (Teleostei: Cichlidae) from the Rio Mamoré system in Bolivia. Bonner Zoologische Beiträge, 36, 145-162.

Koslowski, I. (2002) Die Buntbarsche Amerikas. Vol. 2. Apistogramma \& Co. Eugen Ulmer, Stuttgart, 320 pp.

Kullander, S.O. (1980) A taxonomical study of the genus Apistogramma Regan, with a revision of Brazilian and Peruvian species (Teleostei: Percoidei: Cichlidae). Bonner Zoologische Monographien, 14, 1-152.

Kullander, S.O. (1981) Description of a new species of Apistogramma (Teleostei: Cichlidae) from the upper Amazonas basin. Bonner Zoologische Beiträge, 32, 183-194.

Kullander, S.O. (1982) Cichlid fishes from the La Plata basin. Part II. Apistogramma commbrae (Regan, 1906). Revue suisse de Zoologie, 89, 33-481.

Kullander, S.O. (1983) Cichlid fishes from the La Plata basin. Part IV. Review of the Apistogramma species, with description of a new species. Zoologica Scripta, 11, 307-313. http://dx.doi.org/10.1111/j.1463-6409.1982.tb00541.x

Kullander, S.O. (1986) Cichlid Fishes from the Amazon River Drainage of Peru. Swedish Museum of Natural History, Stockholm, $431 \mathrm{pp}$.

Kullander, S.O. (1990) Mazarunia mazarunii (Teleostei: Cichlidae), a new genus and species from Guyana, South America. Ichthyological Exploration of Freshwaters, 1 (1), 3-14.

Kullander, S.O. (2003) Family Cichlidae (Cichlids). In: Reis, R.E., Kullander, S.O. \& Ferraris, C.J. Jr. (Orgs.), Check list of the freshwater fishes of South and Central America. EDIPUCRS, Porto Alegre, pp. 605-654. [729 pp]

Kullander, S.O. \& Staeck, W. (1988) Description of new Apistogramma species from the Rio Negro in Brazil. Cybium, 12, 189-201.

Ready, J.S., Sampaio, I., Schneider, H., Vinson, C., Dos Santos, T. \& Turner, G.F. (2006) Colour forms of Amazonian cichlid fish represent reproductively isolated species. Journal of Evolutionary Biology, 19, 1139-1148.

http://dx.doi.org/10.1111/j.1420-9101.2006.01088.x

Regan, C.T. (1906) A revision of the South-American cichlid genera Retroculus, Geophagus, Heterogramma and Biotoecus. 
Annals and Magazine of Natural History, 17 (7), 49-66.

http://dx.doi.org/10.1080/00222930608562489

Regan, C.T. (1913) Fishes from the River Ucayali, Peru, collected by Mr. Mounsey. Annals and Magazine of Natural History, $12(8), 281-283$.

http://dx.doi.org/10.1080/00222931308693400

Römer, U. (1994): Apistogramma mendezi nov. spec. (Teleostei:Perciformes; Cichlidae): Description of a New Dwarf Cichlid from the Rio Negro System, Amazonas State, Brazil. Aqua Journal of Ichthyology and Aquatic Biology, 1 (1), 1 - 12.

Schindler, I. \& Staeck, W. (2013) Description of Apistogramma helkeri sp. n., a new geophagine dwarf cichlid (Teleostei: Cichlidae) from the lower río Cuao (Orinoco drainage) in Venezuela. Vertebrate Zoology, 63, 301-306.

Steindachner, F. (1875) Beiträge der Kenntniss der Chromiden des Amazonenstromes. Sitzungsberichte der kaiserlichen Akademie der Wissenschaften. Mathematisch-naturwissenschafliche Classe, 71, 61-137.

Taylor, W.R. \& Van Dyke, G.C. (1985) Revised procedures for staining and clearing small fishes and other vertebrates for bone and cartilage study. Cybium, 9, 107-119. 